Eur. J. Clin. Chem. Clin. Biochem.

Vol. 31, 1993, pp. 545-552

(C) 1993 Walter de Gruyter \& Co.

Berlin - New York

\title{
Determination of Potassium by Dry Reagent Carrier Technology: A Multicentre Evaluation
}

By K. Paschen', P. Hagemann ${ }^{2}$, H. R. M. Lang $^{3}$, M. Cortes $^{4}$, G. Weidemann ${ }^{5}$, J. Toffaletti ${ }^{6}$, Mary Burritt $^{7}$, R. Leinberger ${ }^{8}, W$. Tritschler ${ }^{8}$, Elisabeth Ramstetter ${ }^{8}$ and $P$. Vogel ${ }^{8}$

${ }^{1}$ Klinikum Kaiserslautern, Kaiserslautern, Germany

2 Thurgauisches Kantonsspital, Münsterlingen, Switzerland

${ }^{3}$ Krankenhaus der Stadt Wiener Neustadt, Wiener Neustadt, Austria

${ }^{4}$ Hospital de la Santa Creu i Sant Pau, Barcelona, Spain

${ }^{5}$ Institut für klinische Chemie, Nürnberg, Germany

6 Duke University Medical Center, Durham NC, USA

7 Division of Laboratory Medicine Mayo Clinic/Foundation, Rochester MN USA

8. Boehringer Mannheim GmbH, Mannheim, Germany

(Received February 25, 1992/April 7, 1993)

Summary: We describe the construction, the reaction principle and the performance of Reflotron ${ }^{\circledR} \mathrm{K}^{+}$, a new Reflotron ${ }^{\circledR}$ test for the quantitative determination of potassium in serum and heparinized plasma.

The reaction principle is based on the introduction of the potassium cation via valinomycin into a non-polar phase; the accompanying loss of protons from the non-polar phase is detected by the colour change of a $\mathrm{pH}$ indicator.

The multicentre evaluation of the reagent carrier system showed in median CVs of $<0.9 \%$ (within-series in heparinized plasmas) and $1.3 \%$ (run-to-run in control sera).

The recovery in control sera was $\pm 4 \%$ for seven laboratories.

In the method comparison with flame emission spectrometry, using sera and heparinized plasma samples, regression analysis yielded correlations with slopes of $1.00 \pm 0.04$ (median slope 1.005) and negligible intercepts.

The reagent carrier system showed a linear response in the measuring range $2-12 \mathrm{mmol} / \mathrm{l}$.

Bilirubin (up to $513 \mu \mathrm{mol} / \mathrm{l}$ ), triacylglycèrols (up to $5,7 \mathrm{mmol} / \mathrm{l}$ ), sodium $(135-189 \mathrm{mmol} / \mathrm{l}$ ) and ammonium ions (up to $590 \mu \mathrm{mol} / 1$ ) did not interfere with the test.

Comparison with the results from flame atomic emission spectrometry shows that the recoveries of Reflotron ${ }^{\otimes} \mathrm{K}^{+}$and the direct potentiometric method are slightly and similarly influenced by total protein.

With a panel of 28 drugs tested, no interference could be detected.

Reflotron ${ }^{\oplus} \mathrm{K}^{+}$provides a precise and reliable procedure for the measurement of potassium in serum and heparinized plasma. 


\section{Introduction}

The determination of potassium in serum or plasma is important in emergency cases and for monitoring dyskalaemia and its therapy. Both hyperkalaemia or hypokalaemia, if severe, are dangerous, and must be treated immediately.

The commonly used methods for the determination of potassium concentrations are flame atomic emission spectrometry (FAES) and potentiometric measurements with ion selective electrodes (ISE). The relatively expensive instruments required are standard equipment in every clinical laboratory, but not in the physician's office. The laboratories are, however, frequently too far away from the office to perform potassium determinations in emergency situations. To allow simple, reliable, and quick potassium determinations in the physician's office a test based on dry reagent carrier technology was developed (1).

The recently developed dry reagent carrier Reflotron ${ }^{\circledR}$ $\mathrm{K}^{+}$employs a new technology for potassium determination by using a valinomycin-coupled colour reaction. It completes the analyte menu of the Reflotron ${ }^{\circledR}$ system for the quantitative analysis of clinicochemical analytes in undiluted samples.

The basic chemical reaction and the construction of the dry reagent carrier of the new test are described here together with the results of a multicentre evaluation.

\section{Test Principle of Reflotron ${ }^{\circledR} \mathrm{K}^{+}$and Structure of the Reagent Carrier}

The structure of the Reflotron ${ }^{\otimes} \mathrm{K}^{+}$reagent carrier is shown in figure 1.

For potassium determination with Reflotron ${ }^{\circledR} \mathrm{K}^{+}$, $30 \mu \mathrm{l}$ of sample are applied to the yellow protective

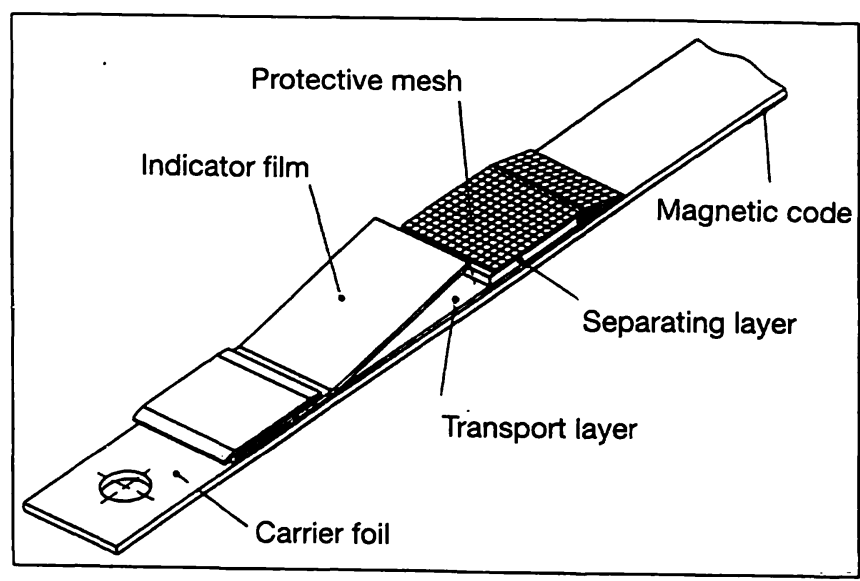

Fig. 1. Structure of the Reflotron ${ }^{\star} \mathrm{K}^{+}$reagent carrier. mesh. The sample is then transported via two different glass fibre layers (the separating layer and the transport layer) to the reaction zone below the hinged part. All the reagents necessary for detecting potassium are contained in this reaction zone (indicator film).

All chemical reactions take place in this reaction film in a combination of a non-polar/water-insoluble phase and an aqueous phase.

The non-polar phase contains valinomycin as a potassium carrier, a $\mathrm{pH}$ indicator and an organic acid (nitronaphthol derivative) (fig. 2).

The potassium cation $\left[\mathrm{K}^{+}\right]$is introduced via valinomycin into the non-polar phase where it is specifically bound as a charged complex. As a result of the change in charge, ion exchange takes place and the $\mathrm{pH}$ indicator releases a proton $\left[\mathrm{H}^{+}\right]$to the aqueous plasma/ serum phase. The organic acid may also release a proton, thus forming a colourless anion to compete with the indicator and to optimize the intensity of the colour formed (fig. 3).
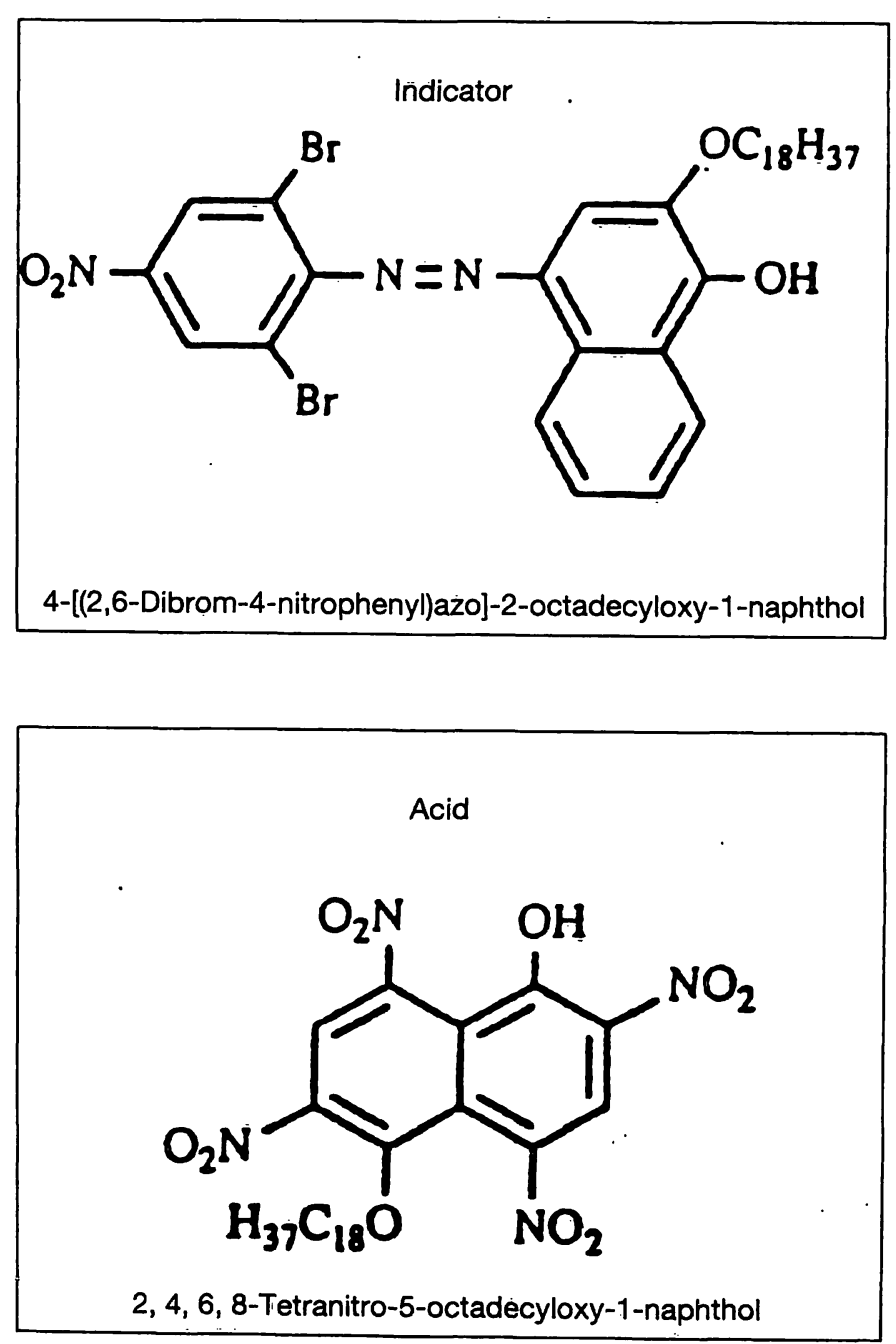

Fig. 2. Structure of the $\mathrm{pH}$ indicator and the organic acid (nitronaphthol derivative) used in the test principle of Reflotron ${ }^{\oplus} \mathrm{K}^{+}$. 


$\begin{array}{|cccc|}\begin{array}{c}\text { Non-polar phase } \\ \text { Val } \\ \text { I-H }\end{array} & \begin{array}{c}\text { Aqueous phase } \\ \text { A-H }\end{array} & \mathrm{K}^{+} \rightleftharpoons \begin{array}{c}\text { Non-polar phase } \\ \text { (al- } K)^{+} \mathrm{I}^{-}\end{array} & \begin{array}{c}\text { Aqueous phase } \\ \text { or } \\ (\mathrm{Nal}-\mathrm{K})^{+} \mathrm{A}^{-}\end{array} \\ \end{array}$

Val: valinomycin

$\mathrm{H}-\mathrm{H}$ : indicator acid

I-: indicator anion

$\mathrm{K}^{+}$: potassium ion

A-H: acid

$A^{-}$: acid anion

Fig. 3. Test principle of Reflotron $\mathrm{K}^{+}$.

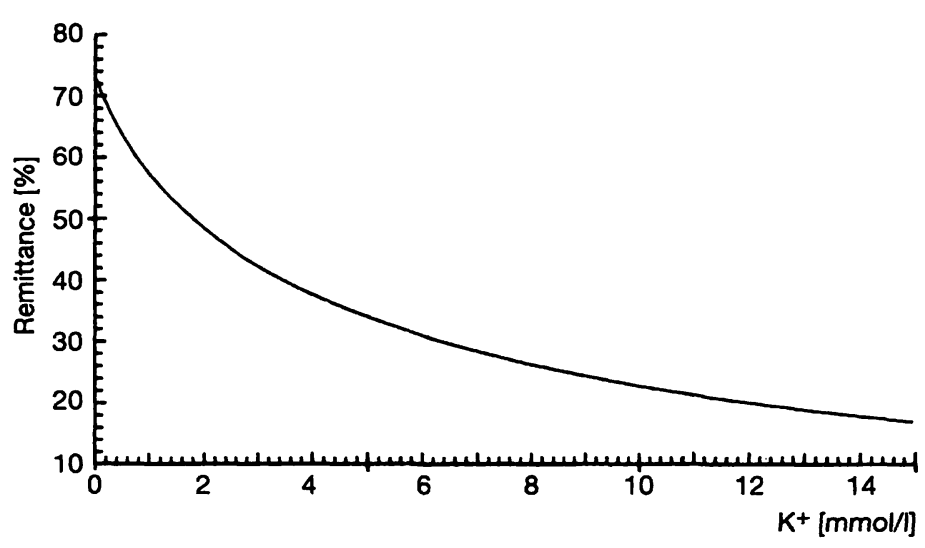

Fig. 4. Calibration curve of Reflotron $\mathrm{K}^{+}$.

The intensity of the colour change of the $\mathrm{pH}$ indicator is proportional to the potassium concentration in the sample. It is measured by reflectance photometry at $642 \mathrm{~nm}$ and the result is displayed after approximately $150 \mathrm{~s}$.

It is well known that haemolysis, or considerable admixture of potassium due to damage to tissue cells during capillary blood collection, can lead to falsely elevated potassium values. To avoid this, the use of venous serum or heparinized plasma as sample material is recommended.

Reflotron ${ }^{\circledR} \mathrm{K}^{+}$was calibrated against the FAES (see fig. 4 for calibration curve) using the same procedure as with the other Reflotron ${ }^{\circledR}$ tests $(2,3)$. The calibrators were prepared from serum and checked for normal protein content (about $70 \mathrm{~g} / \mathrm{l}$ ). The sample material was shock-frozen and stored at $-20^{\circ} \mathrm{C}$.

\section{Materials and Methods}

A basic description of the Reflotron ${ }^{\star}$ instrument has been given previously $(3,4)$.

The analytical performance of Reflotron ${ }^{\oplus} \mathrm{K}^{+}$was examined in a multicentre evaluation at seven sites following the same protocol (5).
In each laboratory, lithium heparinate-treated plasma samples of 5 concentration ranges were measured within-series in tenfold determinations with the reagent carriers and various comparison methods in the framework of the imprecision study. The median, minimum and maximum imprecisions were determined for each concentration range and each comparison method. The run-to-run imprecision was measured in 14 to 82 runs at each laboratory using control sera Precinormit $U$ and Precipath $^{\oplus}$ U for Reflotron ${ }^{\oplus}$. Both control sera also served for the daily quality control of the reagent carrier system and the comparison methods.

The accuracy of Reflotron $\mathrm{K}^{+}$was ascertained by method comparisons with serum and heparinized plasma samples. For this purpose, the same control sera (Reflotron ${ }^{\text {sis }}$ Precinorm $^{\text {is }} \mathrm{U}$, Reflotron ${ }^{\otimes}$ Precipath $^{\oplus} \mathrm{U}$ ) were included in the runs at the 7 evaluation sites. The target values for Reflotron ${ }^{*} \mathrm{~K}^{+}$were determined by Boehringer Mannheim prior to the study, using different instruments. For the ISE methods, an orienting value ascertained in 2 laboratories (Laboratory 1 and Boehringer Mannheim Evaluation Diagnostics) was used instead of a target value. For flame photometry, preliminary target values were used which were later replaced by the values obtained with the official reference method of the German Society for Clinical Chemistry (6).

In the method comparison experiments, $\mathrm{K}^{+}$was determined in serum and heparinized plasma samples $(81-260$ samples per site), using Reflotron ${ }^{(1)} \mathrm{K}^{+}$and the various comparison methods (tab. 3). The regression analysis was performed according to the recommendations of Passing \& Bablok $(7,8)$.

The linearity of the reagent carrier system was checked by analysing samples at 11 different concentrations. These were obtained by mixing different aliquots of two plasmas with potassium concentrations of $11.38 \mathrm{mmol} / \mathrm{l}$ and $2.51 \mathrm{mmol} / 1$ respectively.

The interference study for the detection of potential interferents was performed at evaluation site 8 relative to FAES (IL 953, Instrumentation Laboratory) using heparinized plasma samples.

The relative bias between Reflotron ${ }^{\oplus} \mathrm{K}^{+}$and FAES for different interferents was calculated.

\section{Endogenous substances}

a) 44 plasmas containing bilirubin between 8 and $560 \mu \mathrm{mol} / \mathrm{l}$,

b) 35 plasmas containing triacylglycerols between 0.8 and 6.2 $\mathrm{mmol} / \mathrm{l}$,

c) heparinized plasmas with added sodium and ammonium ions.

The protein dependence of the performance of the reagent carrier method and the ISE method (ISE 2020 analyser, Boehringer Mannheim) relative to FAES was examined using 78 sera with protein concentrations between 28.8 and $130.7 \mathrm{~g} / \mathrm{l}$. The protein concentration was determined by the biuret reaction (9). The protein dependence was assessed by regression analysis of

$$
\frac{\left[\mathrm{K}^{+}\right]_{\text {Renotron }} \mathrm{K}^{+}-\left[\mathrm{K}^{+}\right]_{\text {FAES }}}{\left[\mathrm{K}^{+}\right]_{\text {FAES }}} \times 100 \%
$$

(relative method differences in \%)

versus total protein concentration. The same procedure was used for the protein dependence of the ISE method (ISE 2020 analyser). 


\section{Exogenous influences}

Therapeutic and toxic concentrations of 28 commonly used drugs were tested for interference with the Reflotron ${ }^{\otimes} \mathrm{K}^{+}$ reagent carrier (10).

\section{Results and Discussion}

\section{Imprecision study}

The results of the within-run imprecision study using plasma samples treated with lithium heparinate are summarized in table 1 .

The minimum, median and maximum coefficients of variation obtained for Reflotron ${ }^{\circledR} \mathrm{K}^{+}$and the comparison methods are specified for five concentration ranges.

The Reflotron ${ }^{\circledR} \mathrm{K}^{+}$performed well, showing a median $\mathrm{CV}$ of $\leq 0.9 \%$ in all five concentration ranges. The median CV obtained for FAES is even better (CV $\leq 0.5 \%$ ), while the ISE methods yielded a CV of $\leq 1.0 \%$, which is comparable to that of Reflotron ${ }^{\circledR}$ $\mathrm{K}^{+}$.

The run-to-run imprecision of Reflotron ${ }^{\mathbb{3}} \mathrm{K}^{+}$was determined with the lyophilized control materials, Precinorm ${ }^{\circledR} U$ and Precipath ${ }^{\circledR} U$ for Reflotron ${ }^{\circledR}$. The median CVs obtained for Reflotron ${ }^{\otimes} \mathrm{K}^{+}$, FAES and the ISE methods are very similar (tab. 2), indicating a very good performance of the new dry chemistry system, Reflotron ${ }^{\boxplus} \mathrm{K}^{+}$.

These results show that the reagent carrier system clearly fulfills the requirements with respect to analytical precision $(\mathrm{CV}<2.4 \%)(6,11)$.

\section{Measuring range}

The results of the linearity experiment are illustrated in figure 5. The maximum deviation from the regression line of the values measured with Reflotron ${ }^{\circledast} \mathrm{K}^{+}$ for the 11 aliquots (with potassium concentrations from 2.51 to $11.38 \mathrm{mmol} / \mathrm{l}$ ) was less than $1.9 \%$.

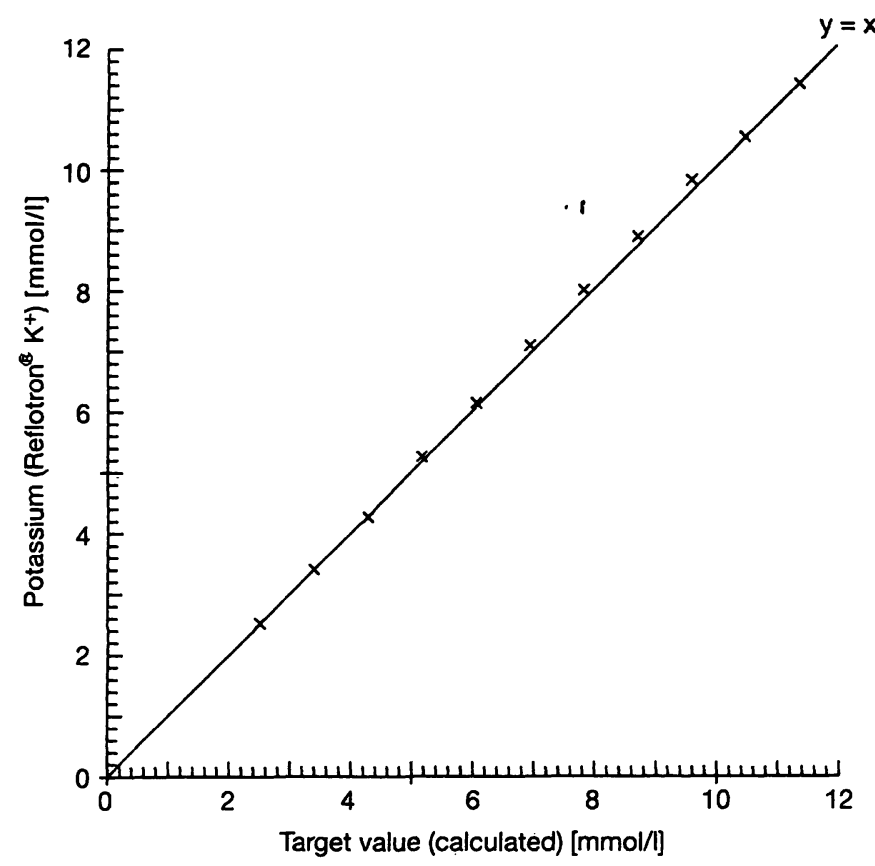

Fig. 5. Linearity of Reflotron ${ }^{\oplus} \mathrm{K}^{+}$. $y=-0.006+1.00 x$

This experiment verifies the linearity of the reagent carrier system in the measuring range from $2-12$ mmol/l claimed by the manufacturer.

\section{Accuracy of $\mathrm{K}^{+}$assay in control sera}

Table 2 shows that the recovery of the target values in control sera with Reflotron ${ }^{\circledR} \mathrm{K}^{+}$in the 7 laboratories was approx. $101 \%(100 \pm 4 \%)$, while a $100 \%$ recovery was obtained for the reference method value of flame photometry $(100 \pm 2 \%)$ and the orienting value of the ISE methods $(100 \pm 6 \%)$. The excellent recovery of the reference method value for flame photometry is a prerequisite for the assessment of the results from the method comparisons.

It has to be mentioned that there are marked differences $(5-7 \%)$ in the target values for the reagent carrier system and FAES. As shown below, control sera and original human sample material obviously behave differently in the reagent carrier system and the FAES method.

Tab. 1. Within-run imprecision of Reflotron ${ }^{\oplus} \mathrm{K}^{+}$using plasma samples treated with lithium heparinate $(\mathrm{n}=10)$.

\begin{tabular}{|c|c|c|c|c|c|c|c|c|c|c|}
\hline \multirow{2}{*}{$\begin{array}{l}\text { Concentration } \\
\text { range } \\
{[\mathrm{mmol} / \mathrm{l}]}\end{array}$} & \multirow{2}{*}{$\begin{array}{l}\text { Number } \\
\text { of } \\
\text { samples }\end{array}$} & \multicolumn{3}{|c|}{$\begin{array}{l}\text { CV [\%] } \\
\text { Reflotron } \mathrm{K}^{+}\end{array}$} & \multicolumn{3}{|c|}{$\begin{array}{l}\text { CV [\%] } \\
\text { FAES }\end{array}$} & \multicolumn{3}{|c|}{$\begin{array}{l}\text { CV [\%] } \\
\text { ISE methoḍs }\end{array}$} \\
\hline & & $\min$ & median & $\max$ & $\min$ & median & $\max$ & $\min$ & median & $\max$ \\
\hline $2.6-3.0$ & 3 & 0.7 & 0.9 & 1.2 & 0.3 & 0.5 & 1.2 & 0.7 & 1.0 & 1.1 \\
\hline $3.0-4.0$ & 10 & 0.6 & 0.8 & 1.4 & 0.2 & 0.5 & 1.1 & 0 & 0.8 & 1.1 \\
\hline $4.0-5.0$ & 5 & 0.4 & 0.8 & 2.6 & 0.2 & 0.4 & 0.4 & 0 & 0.4 & 0.7 \\
\hline $5.0-6.0$ & 5 & 0.3 & 0.7 & 1.2 & 0.2 & 0.3 & 0.4 & $0.2^{\prime}$ & 0.5 & 1.1 \\
\hline $6.0-6.8$ & 5 & 0.4 & 0.5 & 0.5 & 0.1 & 0.3 & 1.0 & 0.5 & 0.5 & 0.7 \\
\hline
\end{tabular}




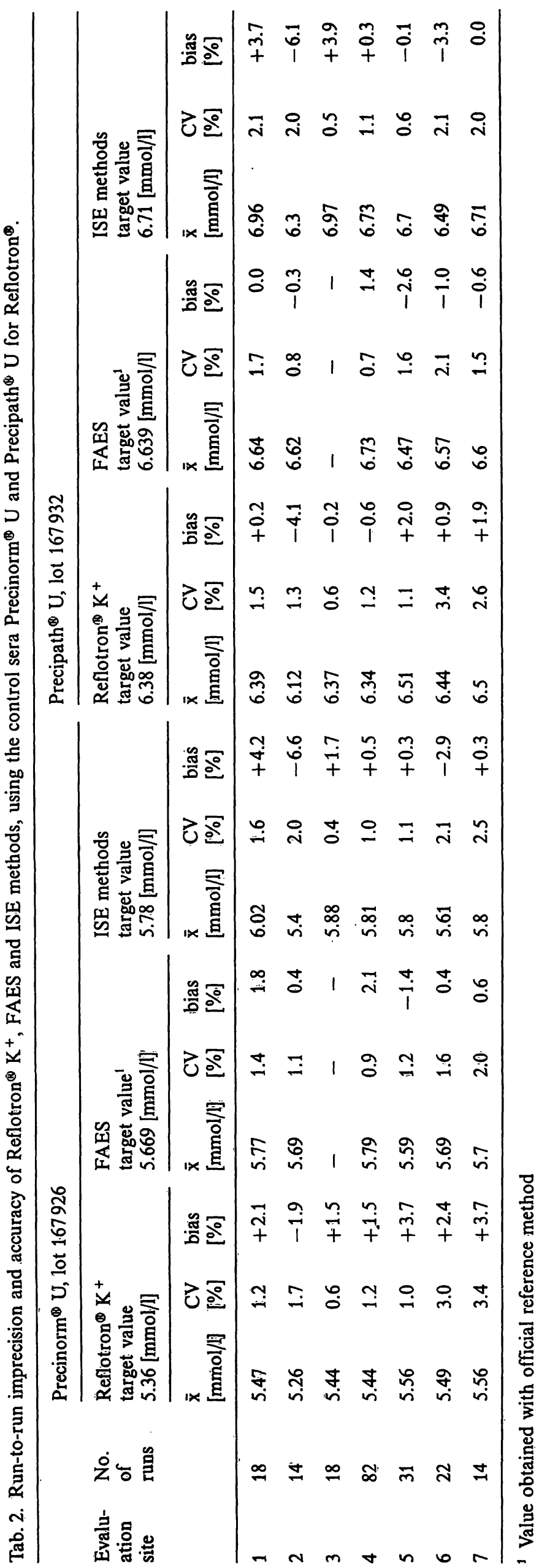

Accuracy of $\mathrm{K}^{+}$assay in sera and heparin plasmas

The results of the method comparison experiments of seven laboratories are summarized in table 3. Most laboratories measured serum or heparin-treated plasma samples with the reagent carrier system and

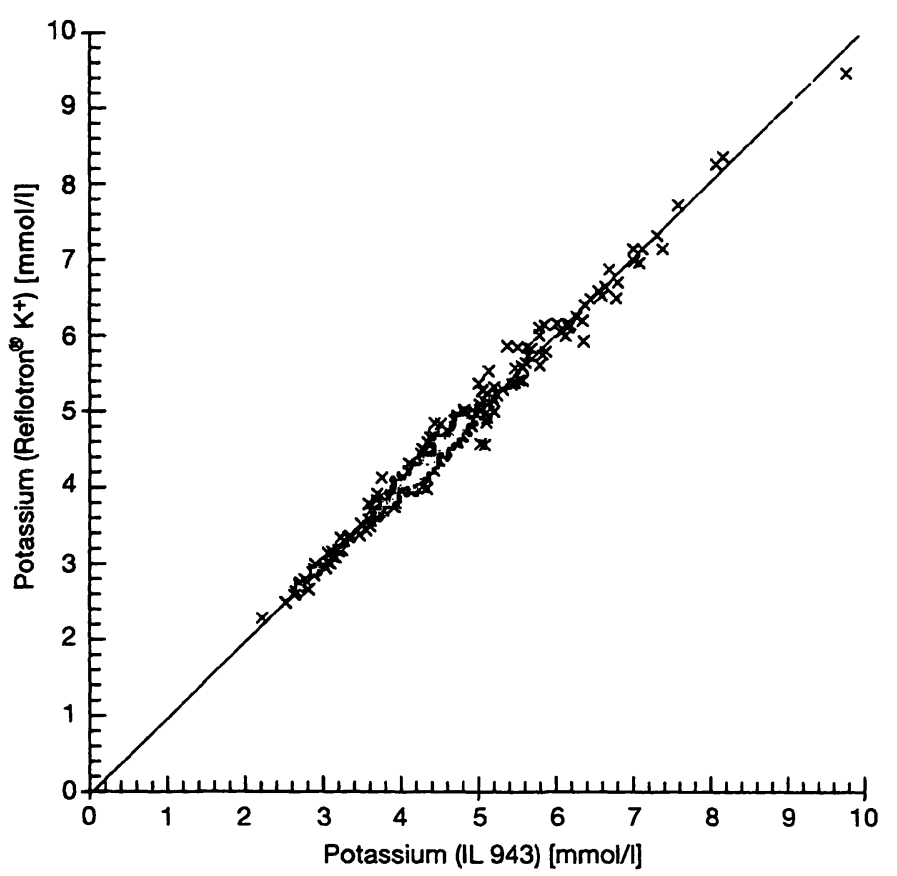

Fig. 6. Comparison of Reflotron ${ }^{10} \mathrm{~K}^{+}$and FAES (IL 943) for the determination of serum $\mathrm{K}^{+}$;

regression data:

$y=-0.0497+1.01 x ; r=0.992 ; n=260$.

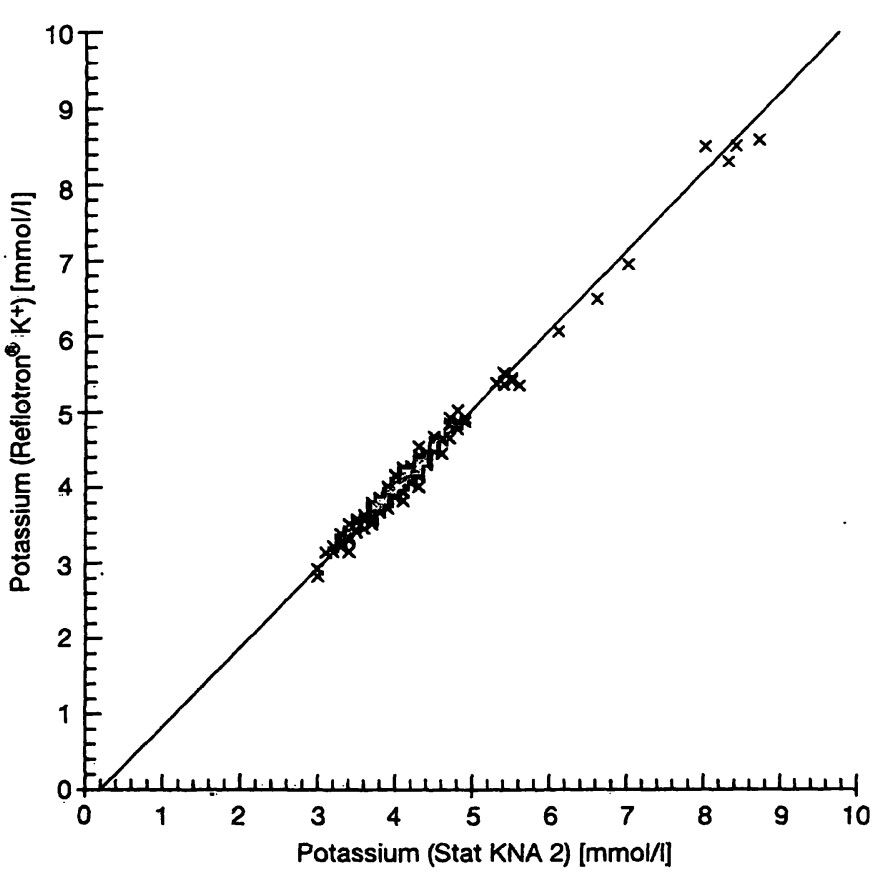

Fig. 7. Comparison of Reflotron $\mathrm{K}^{+}$and ISE method (Nova Stat KNA 2) for the determination of $\mathrm{K}^{+}$in heparinized venous plasma; regression data: $y=-0.220+1.05 x ; r=0.993 ; n=168$. 
Tab. 3. Comparison Reflotron ${ }^{*} \mathrm{~K}^{+}$versus FAES and ISE methods.

\begin{tabular}{|c|c|c|c|c|c|c|c|}
\hline $\begin{array}{l}\text { Evaluation } \\
\text { site }\end{array}$ & Sample & $\begin{array}{l}\text { No. of } \\
\text { samples }\end{array}$ & Comparison method & $\begin{array}{l}\text { Concentration } \\
\text { range } \\
{[\mathrm{mmol} / 1]}\end{array}$ & Slope & $\begin{array}{l}\text { Intercept } \\
{[\mathrm{mmol} / 1]} \\
.1\end{array}$ & $\begin{array}{l}\text { Coefficient } \\
\text { of } \\
\text { correlation }\end{array}$ \\
\hline 1 & $\begin{array}{l}\text { serum } \\
\text { serum } \\
\text { serum } \\
\text { plasma } \\
\text { plasma } \\
\text { plasma }\end{array}$ & $\begin{array}{l}260 \\
260 \\
260 \\
111 \\
111 \\
111\end{array}$ & $\begin{array}{l}\text { FAES (IL 943) } \\
\text { ISE (AVL 982-S) } \\
\text { ISE (Hitachi 717) } \\
\text { FAES (IL 943) } \\
\text { ISE (AVL 982-S) } \\
\text { ISE (Hitachi 717) }\end{array}$ & $\begin{array}{l}2.2-9.8 \\
2.3-10.2 \\
2.0-9.3 \\
3.0-6.4 \\
3.2-7.0 \\
3.2-6.8\end{array}$ & $\begin{array}{l}1.011 \\
0.925 \\
1.062 \\
1.000 \\
0.904 \\
1.000\end{array}$ & $\begin{array}{l}-0.05 \\
+0.09 \\
-0.24 \\
+0.03 \\
+0.25 \\
-0.12\end{array}$ & $\begin{array}{l}0.992 \\
0.980 \\
0.929 \\
0.969 \\
0.975 \\
0.944\end{array}$ \\
\hline 2 & $\begin{array}{l}\text { plasma } \\
\text { plasma }\end{array}$ & $\begin{array}{l}91 \\
91\end{array}$ & $\begin{array}{l}\text { FAES (IL 943) } \\
\text { ISE (IL 501) }\end{array}$ & $\begin{array}{l}3.2-6.5 \\
2.8-6.4\end{array}$ & $\begin{array}{l}0.972 \\
0.992\end{array}$ & $\begin{array}{l}+0.02 \\
+0.04\end{array}$ & $\begin{array}{l}0.991 \\
0.984\end{array}$ \\
\hline 3 & $\begin{array}{l}\text { serum } \\
\text { serum }\end{array}$ & $\begin{array}{l}144 \\
144\end{array}$ & $\begin{array}{l}\text { ISE (ISE 2020) } \\
\text { ISE (Hitachi 737) }\end{array}$ & $\begin{array}{l}2.8-6.4 \\
2.8-6.2\end{array}$ & $\begin{array}{l}0.947 \\
1.019\end{array}$ & $\begin{array}{l}+0.03 \\
-0.11\end{array}$ & $\begin{array}{l}0.989 \\
0.990\end{array}$ \\
\hline 4 & $\begin{array}{l}\text { serum } \\
\text { serum } \\
\text { plasma } \\
\text { plasma }\end{array}$ & $\begin{array}{l}210 \\
210 \\
201 \\
201\end{array}$ & $\begin{array}{l}\text { FAES (IL 943) } \\
\text { ISE (Nova I) } \\
\text { FAES (IL 943) } \\
\text { ISE (Nova I) }\end{array}$ & $\begin{array}{l}2.6-6.6 \\
2.6-6.6 \\
2.7-7.8 \\
2.7-7.8\end{array}$ & $\begin{array}{l}0.975 \\
0.987 \\
0.980 \\
0.973\end{array}$ & $\begin{array}{r}-0.02 \\
-0.08 \\
-0.03 \\
0.00\end{array}$ & $\begin{array}{l}0.961 \\
0.964 \\
0.992 \\
0.995\end{array}$ \\
\hline 5 & $\begin{array}{l}\text { plasma } \\
\text { plasma }\end{array}$ & $\begin{array}{l}223 \\
225\end{array}$ & $\begin{array}{l}\text { FAES (Eppendorf 6341) } \\
\text { ISE (Beckman Astra 8) }\end{array}$ & $\begin{array}{l}2.1-9.5 \\
2.2-10.9\end{array}$ & $\begin{array}{l}1.041 \\
1.011\end{array}$ & $\begin{array}{l}-0.06 \\
-0.06\end{array}$ & $\begin{array}{l}0.993 \\
0.990\end{array}$ \\
\hline 6 & $\begin{array}{l}\text { plasma } \\
\text { plasma } \\
\text { plasma }\end{array}$ & $\begin{array}{r}168 \\
168 \\
81\end{array}$ & $\begin{array}{l}\text { FAES } \\
\text { ISE (Nova Stat KNA 2) } \\
\text { ISE (Beckman CX3) }\end{array}$ & $\begin{array}{l}3.0-9.0 \\
3.0-8.7 \\
3.0-5.8\end{array}$ & $\begin{array}{l}1.043 \\
1.050 \\
0.976\end{array}$ & $\begin{array}{l}-0.19 \\
-0.22 \\
-0.09\end{array}$ & $\begin{array}{l}0.984 \\
0.993 \\
0.938\end{array}$ \\
\hline 7 & $\begin{array}{l}\text { plasma } \\
\text { plasma }\end{array}$ & $\begin{array}{l}200 \\
200 \\
\end{array}$ & $\begin{array}{l}\text { FAES (IL 943) } \\
\text { ISE (Beckman CX3) }\end{array}$ & $\begin{array}{l}2.4-6.9 \\
2.4-7.2 \\
\end{array}$ & $\begin{array}{l}1.040 \\
0.991 \\
\end{array}$ & $\begin{array}{l}-0.16 \\
+0.02 \\
\end{array}$ & $\begin{array}{l}0.982 \\
0.990 \\
\end{array}$ \\
\hline
\end{tabular}

two comparison methods, i.e. flame atomic emission spectrometry and the direct ISE method. Two method comparisons are shown in figures 6 (versus FAES) and 7 (versus ISE).

In the method comparison with FAES, the slopes of the regression lines ranged between 0.972 and 1.043 (median slope 1.005). The intercepts were in most cases negligible (range -0.06 to $+0.03 \mathrm{mmol} / \mathrm{l}$ ) with two exceptions, at sites 6 and 7 , of -0.19 and -0.16 $\mathrm{mmol} / \mathrm{l}$. In both cases a slope of 1.04 was partly counterbalanced by the negative intercept.

In the method comparisons versus the direct ISE method, the slopes of the regression lines were somewhat less close, ranging between 0.904 and 1.050 (median slope 0.987). These results reflect the trend seen in the recoveries of the ISE methods with control sera.

Thus, the results obtained with the reagent carrier system and with the FAES method show excellent comparability. The same is true for the comparison with the direct ISE method, especially since three sites used a slightly biased ISE comparison method.

The method comparison, Reflotron ${ }^{(1)} \mathrm{K}^{+}$versus FAES, is based on the analysis of 1464 human samples. As a criterion for agreement between the two methods for individual samples, a relative bias of $8 \%$ was chosen according to 1 . c. $(11,12)$, i.e. the maxi- mum prescribed deviation between the value measured under routine conditions and the target value (measured by reference method) is $8 \%$. Of 1464 samples measured, only $4.2 \%$ were biased by more than $8 \%$ relative to the FAES results.

Taking into account that the FAES results in this study are assessed under routine conditions with a bias of their own and not by means of a reference method, the results of the Reflotron ${ }^{\circledR} \mathrm{K}^{+}$and FAES show good agreement. The Reflotron ${ }^{\circledR} \mathrm{K}^{+}$is therefore suitable for use in the doctor's office, particularly for emergency situations.

The method comparison with the direct ISE method is based on the results of 1095 samples, after excluding the results of two laboratories with a systematic bias of $>5 \%$. It is interesting that only $2.1 \%$ of the samples yielded a bias of $>8 \%$ between the two methods. The reagent carrier system and the direct ISE methods obviously show a higher degree of agreement for individual samples, which is also reflected in the protein dependence study (see below). One reason is perhaps the use of valinomycin in both methods.

\section{Interference study}

Using native human material, no interference could be detected by bilirubin up to $513 \mu \mathrm{mol} / \mathrm{l}$, or triacyl- 
Tab. 4. Interference study on Reflotron ${ }^{*} \mathrm{~K}^{+}$.

\begin{tabular}{lcc}
\hline $\begin{array}{l}\text { Constituent, } \\
\text { condition }\end{array}$ & Concentration & Recovery \\
\hline Bilirubin & $8 \mu \mathrm{mol} / 1$ & $98 \%$ \\
& $17 \mu \mathrm{mol} / 1$ & $99 \%$ \\
& $85 \mu \mathrm{mol} / 1$ & $100 \%$ \\
& $170 \mu \mathrm{mol} / 1$ & $100 \%$ \\
& $342 \mu \mathrm{mol} / 1$ & $100 \%$ \\
Triacylglycerols & $513 \mu \mathrm{mol} / 1$ & $103 \%$ \\
& $1.1 \mathrm{mmol} / 1$ & $98 \%$ \\
& $2.3 \mathrm{mmol} / 1$ & $100 \%$ \\
$\mathrm{NH}_{4}^{+}$ & $3.4 \mathrm{mmol} / 1$ & $100 \%$ \\
& $5.7 \mathrm{mmol} / 1$ & $100 \%$ \\
Na ${ }^{+}$ & $29 \mu \mathrm{mol} / 1$ & $100 \%$ \\
& $590 \mu \mathrm{mol} / 1$ & $99 \%$ \\
& $135 \mathrm{mmol} / 1$ & $100 \%$ \\
& $140 \mathrm{mmol} / 1$ & $100 \%$ \\
& $155 \mathrm{mmol} / 1$ & $99 \%$ \\
& $173 \mathrm{mmol} / 1$ & $101 \%$ \\
Sample volume & $189 \mathrm{mmol} / 1$ & $103 \%$ \\
applied & $26 \mu \mathrm{l}$ & $90 \%$ \\
& $28 \mu \mathrm{l}$ & $100 \%$ \\
& $30 \mu \mathrm{l}$ & $100 \%$ \\
& $32 \mu \mathrm{l}$ & $102 \%$ \\
\hline
\end{tabular}

glycerols up to the maximum concentrations tested (tab. 4).

Interference by sodium was investigated by supplementing plasma (containing $135 \mathrm{mmol} / \mathrm{l}$ sodium) with sodium chloride. Interference was observed only above $189 \mathrm{mmol} / \mathrm{l}$ sodium. Reflotron ${ }^{\oplus} \mathrm{K}^{+}$test results are therefore unaffected by normal sodium concentrations, and are similarly unaffected by pathologically high or low concentrations.

Also, ammonium ions, in concentrations up to 20 times those found in plasma samples treated with ammonium heparinate, were found to have no effect on the recovery. This sample material can therefore be used on Reflotron ${ }^{\circledast} \mathrm{K}^{+}$.

The $\mathrm{K}^{+}$recovery of the reagent carrier system in dependence on the sample volume is shown in table 4. The indifference of the reagent carrier to the amount of sample volume applied (28 to $32 \mu \mathrm{l}$ are allowed) ensures that reliable results are obtained even when slightly varying sample volumes are applied by inexperienced operators. Serious pipetting errors, i.e. sample volumes differing by more than $10 \%$ from the recommended volume, must be avoided.

The results of the drug interference study (tab. 5) show that neither toxic nor therapeutic concentrations of 28 commonly used drugs were found to have any marked influence on the $\mathrm{K}^{+}$recovery of Reflotron ${ }^{\oplus}$ $\mathrm{K}^{+}$(recovery $100 \pm 5 \%$ ).
Tab. 5. Drug interference study on Reflotron ${ }^{\text {itg }} \mathrm{K}^{+}$.

List of drugs and their concentrations examined in the study.

\begin{tabular}{lrr}
\hline Drug & \multicolumn{2}{c}{ Concentration } \\
& [mg/l] & \\
\cline { 2 - 3 } & $\mathrm{I}$ & $\mathrm{II}$ \\
\hline Acetylsalicylic acid & 1000 & 300 \\
Ampicillin & 1000 & 200 \\
Ascorbic acid & 300 & 30 \\
Bezafibrat & 100 & 10 \\
Carbochromen & 30 & 3 \\
Cephalosporin & 200 & 20 \\
Chloramphenicol & 200 & 20 \\
Caffeine & 100 & 10 \\
Cyclosporin & 20 & 4 \\
Dobesilatc (Ca) & 200 & 20 \\
Dopamine & 10 & $>1$ \\
Furosemid & 100 & 10 \\
Glibenclamid & 1 & 0.1 \\
Indomethacin & 10 & 1 \\
Methyldopa & 20 & 2 \\
Nicotinic acid & 100 & 10 \\
Nitrofurantoin & 18 & 2 \\
Oxytetracycline & 100 & 20 \\
Paracetamol & 200 & 20 \\
Phenprocoumon & 40 & 4 \\
Phenytoin & 100 & 20 \\
Probenecid & 1000 & 200 \\
Procaine & 10 & 2 \\
Pyridamol (Di) & 20 & 2 \\
Quinidine & 60 & 6 \\
Sulfamethoxazole & 600 & 60 \\
Theophylline & 100 & 10 \\
Trimethoprim & 20 & 2 \\
\hline & & \\
\hline
\end{tabular}

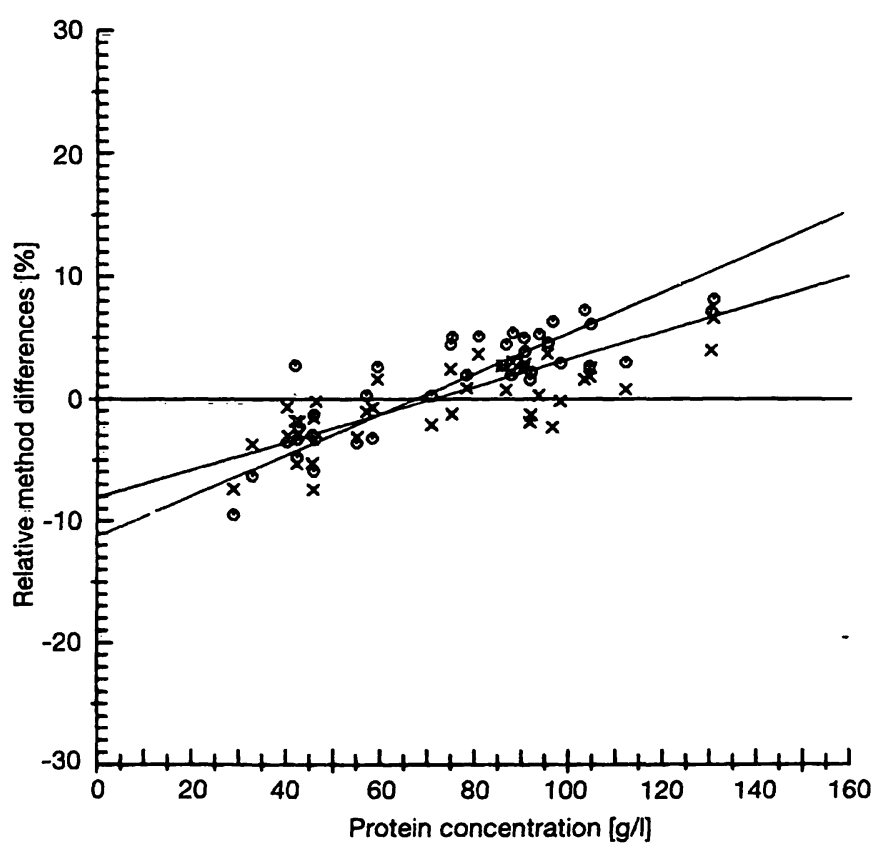

Fig. 8. Protein dependence of results of Reflotron ${ }^{(0)} \mathrm{K}^{+}$and the ISE method (ISE 2020). The percentage differences between results obtained with FAES and those obtained with Reflotron ${ }^{18} \mathrm{~K}^{+}(\mathbf{x})$ and the ISE method $(0)$ are plotted against the concentration of total protein $[\mathrm{g} / \mathrm{l}]$ as determined by the biuret reaction.

$\mathrm{N}=39$ sera

Reflotron ${ }^{\oplus} \mathrm{K}^{+}: \mathrm{y}=-7.92+1.12 \mathrm{x}$

ISE 2020: $y=-11.2+1.68 x$ 


\section{Protein dependence}

Figure 8 shows the protein dependence of potassium determination with Reflotron ${ }^{\oplus} \mathrm{K}^{+}$and the ISE 2020 method relative to FAES.

Since Reflotron ${ }^{\boxplus} \mathrm{K}^{+}$is calibrated using sera with a normal protein content, it was to be expected that the reagent carrier system and FAES would generate identical results for samples with protein concentrations in the reference interval $(60-75 \mathrm{~g} / \mathrm{l})$.

The results of the reagent carrier system, however, differ by $-4.6 \%$ or $+5.5 \%$ from those obtained with FAES when sera with high or low protein contents $(30$ or $120 \mathrm{~g} / \mathrm{l})$ are used. The direct ISE 2020 method shows the same effect as Reflotron ${ }^{\oplus} \mathrm{K}^{+}$, but differs from FAES by $-6.2 \%$ and $+9 \%$, so that its protein dependence is somewhat higher. The results of Reflotron ${ }^{(1)} \mathrm{K}^{+}$are therefore very similar to those obtained with ion selective electrodes.

For the last 20 years it has been well known that the results obtained with the ISE method for sodium and potassium reflect the clinical state of the patient with abnormal protein or lipid concentrations far better than FAES results, because FAES analyses the potassium concentration irrespective the fact that the protein and lipid phase of the serum is free of electrolytes (13). Both the ISE method and Reflotron ${ }^{\star 1}$ $\mathrm{K}^{+}$use valinomycin as an active, selective reagent for the substance to be determined and in both cases the ion activity is measured in the aqueous plasma phase of the undiluted samples.

In conclusion, Reflotron ${ }^{\otimes} \mathrm{K}^{+}$provides a precise and reliable procedure for the measurement of the potassium concentration of serum and heparinized plasma samples. It is particularly suitable in clinical situations that require an immediate result.

\section{Acknowledgement}

We wish to thank Prof. Külpmann and Prof. Büttner, Institut für Klinische Chemie, Medizinische Hochschule Hannover, for ascertaining the reference method values.

\section{References}

1. Charlton, S. C., Fleming, R. L. \& Zipp, A. (1982) Solidphase colorimetric determination of potassium. Clin. Chem. 28, 1857-1861.

2. Anonymous (1991) Calibration of the Reflotron ${ }^{\circledR}$ system. In: What You Always Wanted to Know About Reflotron ${ }^{\circledR}$, pp. 36-43, Boehringer Mannheim GmbH, Mannheim.

3. Steinhausen, R. \& Price, C. P. (1985) Principle and Practice of Dry' Chemistry Systems. Recent Adv. Clin. Biochem., Vol. 3 (Price, C. P. \& Alberti, K. G. M. M., eds.) pp. 273296, Churchill Livinstone, Edinburgh.

4. Price, C. P. \& Koller, P. U. (1988) A multicentre study of the new Reflotron ${ }^{n}$ system for the measurement of urea, glucose, triacylglycerols, cholesterol, $\gamma$-glutamyltransferase and haemoglobin. J. Clin. Chem. Clin. Biochem. 26, 233250.

5. Haeckel, R., Busch, E. W., Jennings, R. D., Kokolm, G. \& Truchand, A. (1986) Guidelines for the evaluation of analyzers in clinical chemistry. ECCLS Document 3, No 2, pp. 1-32, Beuth-Verlag, Berlin-Köln.

6. Anonymous (1988) Richtlinien der Bundesärztekammer zur Qualitätssicherung in medizinischen Laboratorien. Dt. Ärtzebl. 85, 697-712.

7. Passing, H. \& Bablok, W. (1983) A new biometrical procedure for testing the equality of measurements from different analytical methods; Part I. J. Clin. Chem. Clin. Biochem. 21, 709-720.
8. Passing, H. \& Bablok, W. (1984) Comparison of several regression procedures for method comparison studies and determination of sample sizes; Part II. J. Clin. Chem. Clin. Biochem. 22, $431-445$.

9. Doumas, B. T., Bayse, D. D., Carter, R. J., Peters, Jr., Th. \& Schaffer, $R$. (1981) A candidate reference method for determination of total protein in serum. I. Development and validation. Clin. Chem. 27, 1642-1650.

10. Koller, P. U., Tritschler, W. \& Carstensen, C. A. (1989) Interference studies on the Reflotron ${ }^{\circledR}$ system. Lab. Med. $13,399-402$.

11. Fraser, C. G. (1990) Analytical goals are applicable to all. JIFCC 2, 84-86.

12. Fraser, C. G. (1981) Analytical goals in clinical biochemistry. Progr. Clin. Pathol. 8, $101-121$.

13. Paschen, K., Andreae, W., Strobel, W., Gabl, F., Mokricky, C., Flückiger, J. W. S., Hänseler, E., Schlebusch, H., Schneider, Ch., Poppe, W. A. \& Völkert, E. (1985) Elektrolytanalysator ISE 2020. Ergebnisse einer multizentrischen Evaluierung. J. Clin. Chem. Clin. Biochem. 23, 187-196.

Prof. Dr. med. Kai Paschen

Zentrallaboratorium und Blutbank

Klinikum Kaiserslautern

D-67653 Kaiserslautern

Germany 